\title{
Reading Ireland
}

Print, reading and social change IN EARLY MODERN IRELAND

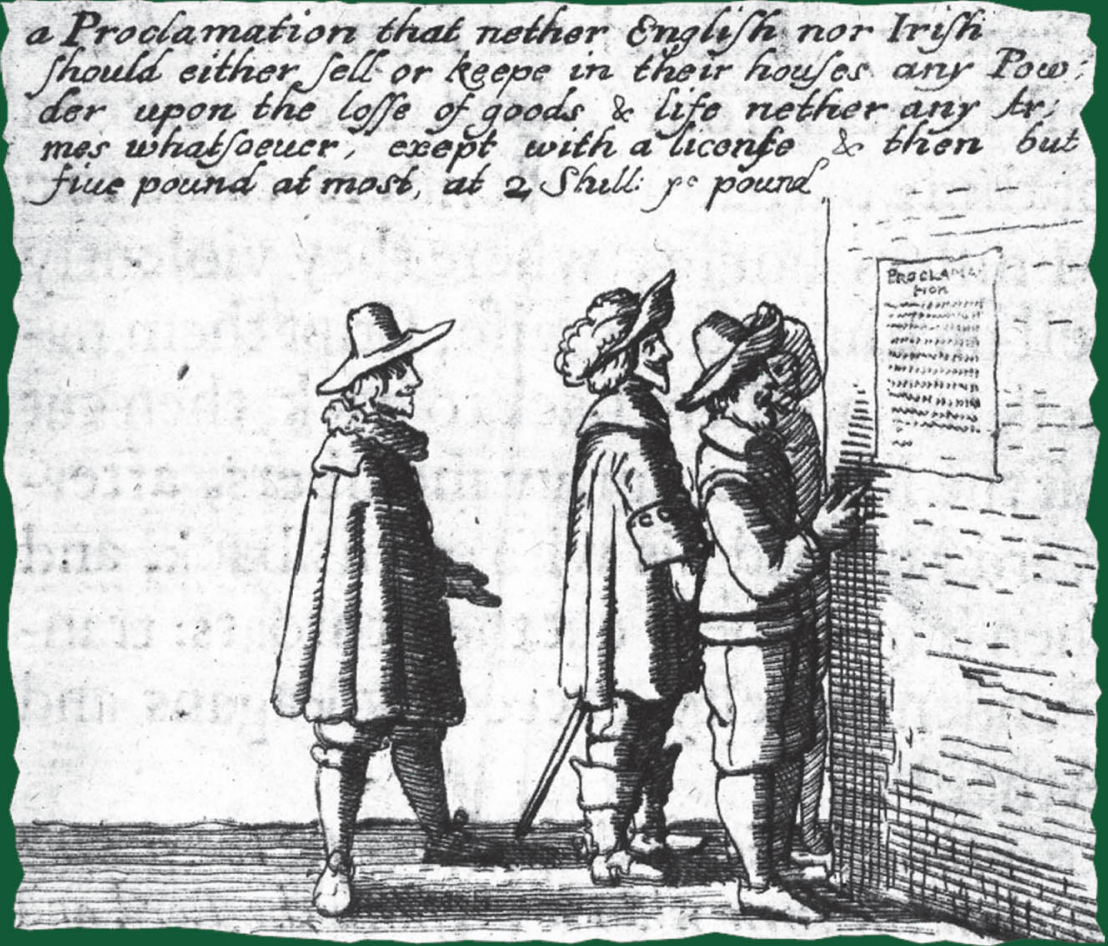




\section{Reading Ireland}

\section{MANCHESTER 1824}

Manchester University Press 


\section{Politics, culture and society in early modern Britain \\ General editors \\ PROFESSOR ANN HUGHES \\ DR ANTHONY MILTON \\ PROFESSOR PETER LAKE}

This important series publishes monographs that take a fresh and challenging look at the interactions between politics, culture and society in Britain between I500 and the mid-eighteenth century. It counteracts the fragmentation of current historiography through encouraging a variety of approaches which attempt to redefine the political, social and cultural worlds, and to explore their interconnection in a flexible and creative fashion. All the volumes in the series question and transcend traditional interdisciplinary boundaries, such as those between political history and literary studies, social history and divinity, urban history and anthropology. They contribute to a broader understanding of crucial developments in early modern Britain.

Already published in the series

Leicester and the Court: essays on Elizabethan politics SIMON ADAMS

Ambition and failure in Stuart England: the career of John, first Viscount Scudamore IAN ATHERTON

Literature and politics in the English Reformation TOM BETTERIDGE

Republican learning: John Toland and the crisis of Christian culture, 1696-1722 JUSTIN CHAMPION

Home divisions: aristocracy, the state and provincial conflict THOMAS COGSWELL

A religion of the world: the defence of the reformation in the reign of Edward VI CATHARINE DAVIES

Cromwell's major-generals: godly government during the English Revolution CHRISTOPHER DURSTON

The English sermon revised: religion, literature and history 1600-1750 LORI ANNE FERRELL and PETER MCCULLOUGH (eds)

The spoken word: oral culture in Britain 1500-1850 ADAM FOX and DANIEL WOOLF (eds)

Londinopolis: essays in the cultural and social history of early modern London PAUL GRIFFITHS AND MARK JENNER (eds)

Inventing a republic: the political culture of the English Commonwealth 1649-1653 SEAN KELSEY

The box maker's revenge: 'orthodoxy', 'heterodoxy' and the politics

of parish in early Stuart London PETER LAKE

Theatre and empire: Great Britain on the London stages under James VI and I TRISTAN MARSHALL

Courtship and constraint: rethinking the making of marriage in Tudor England DIANA O'HARA

Catholics and the 'Protestant nation': religious politics and identity in early modern England ETHAN SHAGAN (ed.)

Communities in early modern England: networks, place, rhetoric ALEXANDRA SHEPARD and PHILIP WITHINGTON (eds)

Aspects of English Protestantism, c. 1530-1700 NICHOLAS TYACKE

Political passions: gender, the family and political argument in England, 1680-1714 RACHEL WEIL 


\title{
Reading Ireland
}

\author{
Print, reading and social change \\ in early modern Ireland
}

\author{
RAYMOND GILLESPIE
}

\author{
Manchester \\ University Press \\ Manchester and New York \\ distributed exclusively in the USA by Palgrave
}


Copyright (C) Manchester University Press 2005

The right of Raymond Gillespie to be identified as the author of this work has been asserted by him in accordance with the Copyright, Designs and Patents Act I9 88

Published by Manchester University Press

Oxford Road, Manchester MI3 9NR, UK

and Room 400, I75 Fifth Avenue, New York, NY IooIo, USA

www.manchesteruniversitypress.co.uk

Distributed exclusively in the USA by

Palgrave, I75 Fifth Avenue, New York, NY IooIo, USA

Distributed exclusively in Canada by

UBC Press, University of British Columbia, 2029 West Mall,

Vancouver, BC, Canada v6r Iz2

British Library Cataloguing-in-Publication Data

A catalogue record for this book is available from the British Library

Library of Congress Cataloging-in-Publication Data applied for

ISBN $071905527 \times$ hardback

EAN 9780719055270

First published 2005

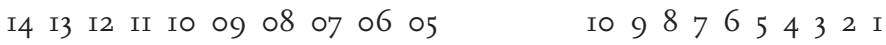

Typeset in Scala with Pastonchi display

by Koinonia Ltd, Manchester

Printed in Great Britain

by CPI, Bath 